\title{
The Impact of Microdata in Norwegian Historiography 1970 to 2020
}

\section{By Hilde L. Sommerseth and Gunnar Thorvaldsen}

To cite this article: Sommerseth, H. L. \& Thorvaldsen, G. (2022). The Impact of Microdata in Norwegian Historiography 1970 to 2020. Historical Life Course Studies, 12, 18-41. https://doi.org/10.51964/hlcs11675

\section{HISTORICAL LIFE COURSE STUDIES}

Major Databases with Historical Longitudinal Population Data: Development, Impact and Results

VOLUME 12 SPECIAL ISSUE 4, 2020

GUEST EDITORS Sören Edvinsson Kees Mandemakers Ken Smith 


\section{HISTORICAL LIFE COURSE STUDIES}

Historical Life Course Studies is the electronic journal of the European Historical Population Samples Network (EHPSNet). The journal is the primary publishing outlet for research involved in the conversion of existing European and nonEuropean large historical demographic databases into a common format, the Intermediate Data Structure, and for studies based on these databases. The journal publishes both methodological and substantive research articles.

\section{Methodological Articles}

This section includes methodological articles that describe all forms of data handling involving large historical databases, including extensive descriptions of new or existing databases, syntax, algorithms and extraction programs. Authors are encouraged to share their syntaxes, applications and other forms of software presented in their article, if pertinent, on the EHPS-Net website.

\section{Research articles}

This section includes substantive articles reporting the results of comparative longitudinal studies that are demographic and historical in nature, and that are based on micro-data from large historical databases.

Historical Life Course Studies is a no-fee double-blind, peer-reviewed open-access journal supported by the European Science Foundation (ESF, http://www.esf.org), the Scientific Research Network of Historical Demography (FWO Flanders, http://www.historicaldemography.be) and the International Institute of Social History Amsterdam (IISH, http://socialhistory.org/). Manuscripts are reviewed by the editors, members of the editorial and scientific boards, and by external reviewers. All journal content is freely available on the internet at hlcs.nl.

\section{Co-Editors-In-Chief:}

Paul Puschmann (Radboud University) \& Luciana Quaranta (Lund University)

hislives@kuleuven.be

The European Science Foundation (ESF) provides a platform for its Member Organisations to advance science and explore new directions for research at the European level. Established in 1974 as an independent non-governmental organisation, the ESF currently serves 78 Member Organisations across 30 countries. EHPS-Net is an ESF Research Networking Programme.

The European Historical Population Samples Network (EHPS-net) brings together scholars to create a common format for databases containing non-aggregated information on persons, families and households. The aim is to form an integrated and joint interface between many European and non-European databases to stimulate comparative research on the micro-level.

Visit: http://www.ehps-net.eu.
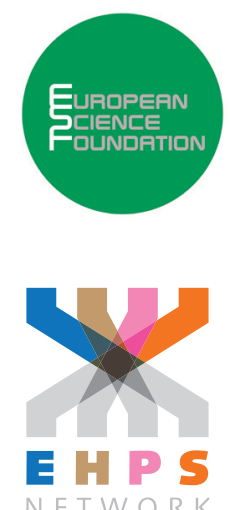


\title{
The Impact of Microdata in Norwegian Historiography 1970 to 2020
}

\author{
Hilde L. Sommerseth \\ UiT The Arctic University of Norway
}

Gunnar Thorvaldsen

Ural Federal University \& UiT The Arctic University of Norway

\section{ABSTRACT}

The establishment of the Norwegian Historical Data Centre, the 1801 project at the University of Bergen and the data transcriptions and scanned versions of the sources in the National Archives made Norwegian microdata much more available. A more detailed description of the digital techniques applied to the wealth of censuses, church records and other types of nominative data from the 18th century onwards, will be presented in a separate article. Our main focus here is to summarize the impact of the research that has been produced based on the Norwegian historical microdata. These studies span a wide range of fields within social history and historical demography: Emigration, immigration, internal migration, fertility, nuptiality, family history and last but not least mortality studies with a priority given to infant mortality. A recent development is the building of a national historical population register covering the 19th and 20th centuries.

Keywords: Norway, Microdata, Censuses, Vital records, Transcription, Migration, Social mobility, Fertility, Mortality, Nuptiality, Family history, Ethnicity, Population register

\author{
e-ISSN: $\quad$ 2352-6343 \\ DOI article: https://doi.org/10.51964/hlcs11675
}

This open-access work is licensed under a Creative Commons Attribution 4.0 International License, which permits use, reproduction \& distribution in any medium for non-commercial purposes, provided the original author(s) and source are given credit. See http://creativecommons.org/licenses/. 


\section{INTRODUCTION}

This article sketches the background of the establishment of the Norwegian Historical Data Centre as part of UiT The Arctic University of Norway. This centre concentrates on data transcriptions and enhanced digital versions of the sources, which have often been developed in cooperation with other database vendors, especially the National Archives. We plan a detailed description of the digital techniques and methods in a separate article. Our focus here is to summarize the impact of the research that has been produced based on the Norwegian historical microdata. The historiographic bottom line is that Norwegian archives abound in censuses, church records and other types of structured individual level data from the 18th century onwards. The advent of the computer from the 1970s onwards helped release these riches and put them at the disposal of students and staff eager to write the population and social history, mostly for local communities or regions (Hubbard, 1995). Since then, we have researched most branches of social and population history, with priority given to studies of mortality, migration and family history. A mixture of methods has been used, for instance fertility has been studied nationally on the municipality level and parish-wise with microdata. While initially researchers used each source separately or with family reconstitution, they are now being linked on the individual level with database techniques. The Norwegian Historical Population Register covering the period from 1800 onwards, is the fruition of this development.

\section{BACKGROUND}

\subsection{THE FIRST COMPUTER PROJECTS ON INDIVIDUAL LEVEL DATA}

Norway's demographic history $1735-1865$ was already written in the 1960s by the English demographer Michael Drake (1969) based on aggregates. Still, due to the focus on political history in Norwegian historiography, we could expect continuity with respect to sources and methods from political to social and demographic history. The leader of the first comprehensive social science history research project, Sivert Langholm, had studied the voters in the capital during the 19th century. And two of the project's central master theses studied the members of the radical Thrane protest movement around 1850 and the Workers' Society [Kristiania Arbeidersamfund], respectively. This project, Norwegian social development 1860 to 1900, started in 1971 in the Department of History at the University of Oslo as a well-funded research and teaching project. It aimed to study 19th century Norwegian social history through a micro historical research program. Thus, it promoted historical data on the individual level, facilitating aggregate results on multiple analysis levels, from individuals and families to the inhabitants of census tracts or whole municipalities. The two contextual locations chosen were the capital Oslo, at the time called Kristiania, and rural Ullensaker, a municipality fifty kilometres further northwest (Langholm, 1974, 1975).

The project developed software for transcribing the local sources, correcting errors, listing and sorting the material. In the HISO software package, developed by future National Archivist Ivar Fonnes, there were also opportunities to translate from full-text to encoded version with numerical codes for the different individual characteristics. The results, however, were made available in aggregated form with standard statistical software. The sources treated in this way were the local censuses of 1865 and 1875, parts of the emigrant books, and for rural Ullensaker the church registers 1845 to 1875 . The biggest source was the 1875 census for Kristiania with 78,000 individuals. In order to defend the high cost of transferring the sources to computers, the project needed many participants, and over 20 students were recruited to write master theses based on the computerized source material. In addition, a number of students were inspired to address related topics for other parts of the country, including family reconstitutions. Both the University of Bergen and of Oslo were inspired by French demographic research especially Louis Henry's method to link church records for the reconstitution of families (Dyrvik, 1983; Sogner, 2016). Central to the topics addressed were social and geographical mobility. Sølvi Sogner (1979) used her reconstitution of rural Rendalen parish to trace outmigration from the relatively isolated valley towards the coast and later on also to the Netherlands and its colonies, employing marriage banns registers from the Amsterdam City Archives (Sogner, 2012). Today we know significantly more about fertility, nuptiality, mortality and family history, about migrants who moved to America and to the cities, about intergenerational social mobility and about typical careers in the 19th century. 
A more advanced use of history oriented computer technology took place in the Department of History at the University of Bergen. Here a project headed by Jan Oldervoll, made the full count census from 1801 with nearly 900,000 records machine-readable and encoded and aggregated the data in cooperation with Statistics Norway (Statistics Norway, 1980). Two master theses were based on record linkage between the 1801 census and the church registers in the surrounding years; cf. Haavet (1982) in the fertility section 6.2 and Engelsen (1983) in the mortality section 4.3. The linking was semi-automatic with automatic normalization of personal names. However, all decisions about which records belonged to the same person were made by manual intervention. Thus, already in the late 1970 s they utilized the opportunities inherent in computers equipped with disk storage and interactive terminals. The new techniques facilitated studying far more individuals; 44 randomly selected parishes with a total of 116,000 people. Thus, the pioneer microdata projects in Norway transcribed the full count 1801 census and the late 19th century censuses and some vital records for the capital and a nearby municipality. These were used to study migration, mortality and a range of other topics within the fields of social and population history.

\subsection{THE NORWEGIAN HISTORICAL DATA CENTRE}

The initiative to establish the Norwegian Historical Data Centre (NHDC) was taken by historians at the University of Tromsø (UiT) in 1976. The Demographic Database (DDB) at Umeå University served as a model, where in 1972 professor of pedagogy and former priest, Egil Johansson, kick-started work on transcribing church books in Haparanda, also originally an employment measure (Edvinsson \& Engberg, 2020; Thorvaldsen, 1998). Data consultant Jan Olav Hauge prepared the first planning document after visiting Umeå University (Thorvaldsen, 1977, 1978). The plans became concrete against the backdrop of the closure of the last remaining manual telephone exchanges, where many women were losing their employment. Due to political pressure from local and regional authorities, including municipality mayors, the labour market authorities, the County Governor and the UiT, funds were allocated for a pilot project in which two telephone operators transcribed selected census and church records under the direction of one of the undersigned (Thorvaldsen, 1979). Thus, a professional basis for the NHDC was established, but financing a permanent undertaking turned out to be difficult. But in 1981, during the Parliament's work on the national fiscal budget, three representatives supposed to support the government, broke ranks and voted for the creation of the Norwegian Historical Data Centre together with the opposition. The UiT received economic support for the establishment of two new units, a management unit located in Tromsø, and a unit for transcription and proofreading 150 kilometres to the southeast.

Although the transcription scope of the NHDC was national, targeting at central nominative sources, the initial regional mission of the UiT dictated a focus on source material from the neighbouring region. This was in demand in demographic and social history research and the material was available at the Regional Archives in Tromsø. Still, a choice of period and type of source material had to be made. The period was limited by the Law of Statistics, which rules that nominative material collected by the state is for statistical use only during the first hundred years (https://www.ssb.no/omssb/lover-ogprinsipper/statistikkloven). Since the legal authority was initially granted by Parliament in 1907, the censuses from 1865, 1875 and 1900 were available anyway, but the 1910 census was blocked until 2010, when the NHDC and the National Archives made transcribed and encoded versions available. The 1891 census was difficult to handle due to the large amount of person sheets that only existed in the original in the National Archives in Oslo. Three censuses thus became a first priority, also because they were in demand both in quantitatively oriented research and in order to trace historical persons. Church records were blocked for eighty years, but in some cases are difficult to use for transcription because there are backlogs of transfer to the regional archives (Thorvaldsen, 1996). Consequently, the three available national censuses and the regional lists of baptisms, marriages and burials from the church books for Troms province was the focus when starting the work in earnest by 1982. The digital versions were encoded and standardized for statistical use and published as printed editions for genealogical use in the relevant municipalities and parishes.

The National Archives allowed volunteering genealogists to access the scanned version of the 1920 census and start transcriptions while promising to share no information before 1 December 2020. The 1891 census was completed in India with most expenses paid by US companies catering to genealogists: Ancestry, My Heritage and FamilySearch. This is part of a deal negotiated by the National Archives, where the said companies also transcribed the church records for the period from 1815 until about 1930. The 1960 and later censuses were transcribed as part of the contemporary aggregation and went into the building of the Central Population Register which covers the period from 1964 
onwards. At the same time, there is much interest in source materials particularly for medical research. We thus need to bridge the time-gap in the mid-20th century. Foremost among these are the 1950 and the 1930 housing and population censuses. These have been scanned by the National Archives as part of our effort to build a Historical Population Register for Norway.

To sum up, by the coordinated efforts of the National Archives and the Norwegian Historical Data Centre, the nominative and full count 1801, 1865, 1875, 1891, 1900 and 1910 censuses have been transcribed, while the censuses from 1920 will be searchable in early 2022. Today, researchers can apply for specific data extraction via our web page, and encoded versions of the censuses until 1910 are also available at the Minnesota Population Center through the North Atlantic Population Project and the Digital Archive of Norway. Our strategic goal for the future is to develop systems for online data extraction and analysis both for our cross-sectional data and our longitudinal register.

Until the microdata revolution from the 1970s, historical research on migration mainly dealt with emigration overseas, but then internal migration became the focus of many studies. At the start of the millennium, immigration received its fair share of the historians' attention. The literature on migration in Norway is too vast, even if we only consider research based on microdata, to be summarized as part of a historiographic article. Therefore, we shall concentrate on specific examples within the fields of internal migration, emigration and immigration, while also citing references to works providing broader overviews where they exist. For a first attempt to summarize Norwegian domestic migration, see (Thorvaldsen, 2019).

\subsection{INTERNAL MIGRATION INSIDE NORWAY}

An extensive dissertation by Thorvaldsen (1995) dedicated to internal migration, mapped geographical mobility in Troms province in Northern Norway during the second half of the 19th century, when net in-migration turned into net out-migration. The 1865, 1875 and 1900 censuses were used crosssectionally and longitudinally to estimate in- and out-migration as well as migration between and inside the municipalities. Then it describes what characterized the internal and the in- and out-migrants. The dissertation studied the development of an entire province ("fylke", sometimes called county) based on individual level data, out-migrants from the municipalities being traced to their new domicile. Software for automatic record linkage was developed and used to trace the migrants longitudinally. The amount of in-migration declined during the period 1865-1900, out-migration from the province increased and internal migration stayed at the same level. The empirical results are summarized in a migration model based on the concept of the frontier. The agricultural crisis in the late 1860's and the urban trade crisis around 1880 ended the province's frontier position and the mass in-migration from other parts of the Nordic countries.

Emigration and other out-migration were small in this region because of several barriers to migration. One barrier was the peasant economy, the combination of fishing and farming absorbing the growing population into the family production units. There was no enclosure movement blocking the peasant families from using the resources in the commons as was the case in the British countryside, forcing many to leave for the cities. A second barrier was ethnic, the Sami tended to stay within the areas they dominated, even when they migrated. A third barrier was social. The farmers and peasants, most of them also fishing, tended to not migrate, explaining why this province had the lowest emigration rates in Norway. The exception was the farming community with roots in southern Norway, who emigrated since they had social contacts in the US. They were a minority of inland farmers who had fewer relationships with the rest of the population in the province. Thus, the multiplier effect on emigration inherent in contiguous social networks (Åkerman, 1978), only marginally showed its potential in this part of thinly populated, topographically divided and ethnically mixed Northern Norway. As expected, people mostly migrated to conserve their old way of life. For the fishing peasants of Troms, it was difficult to keep up this combination of trades if they moved to town. Agriculture was marginal to the north on the coast of Finnmark, there was little room for new farms to the south and small chances to fish on the American prairie. Migration and non-migration were to a high degree related to the economy, peasants tending to stay put, while people in the trades and the services migrated more. The social network was a secondary determinant, helping people to decide about their specific destination (Thorvaldsen, 1995). 
Map 1

Map of Norway

WEST-, EAST- AND SOUTHERN NORWAY

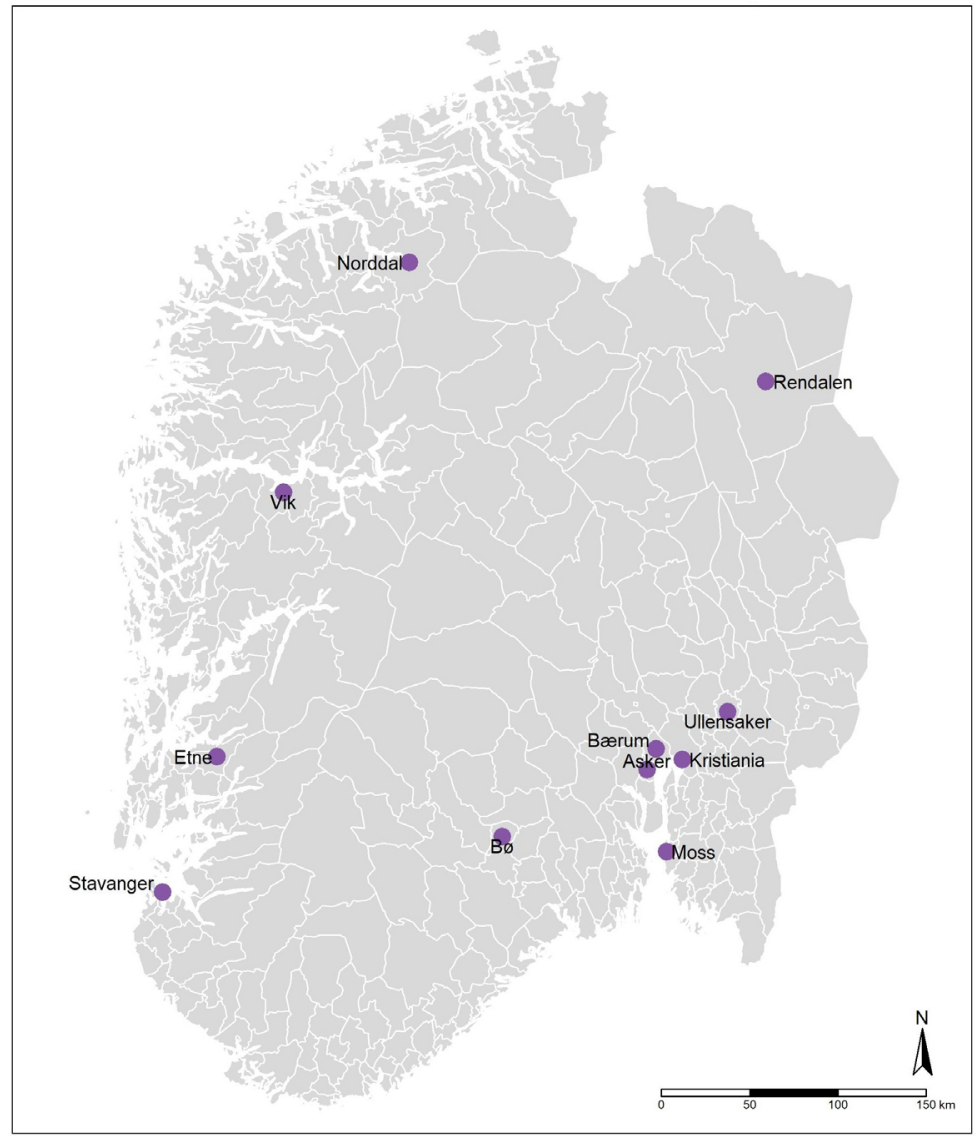

CENTRAL AND NORTHERN NORWAY

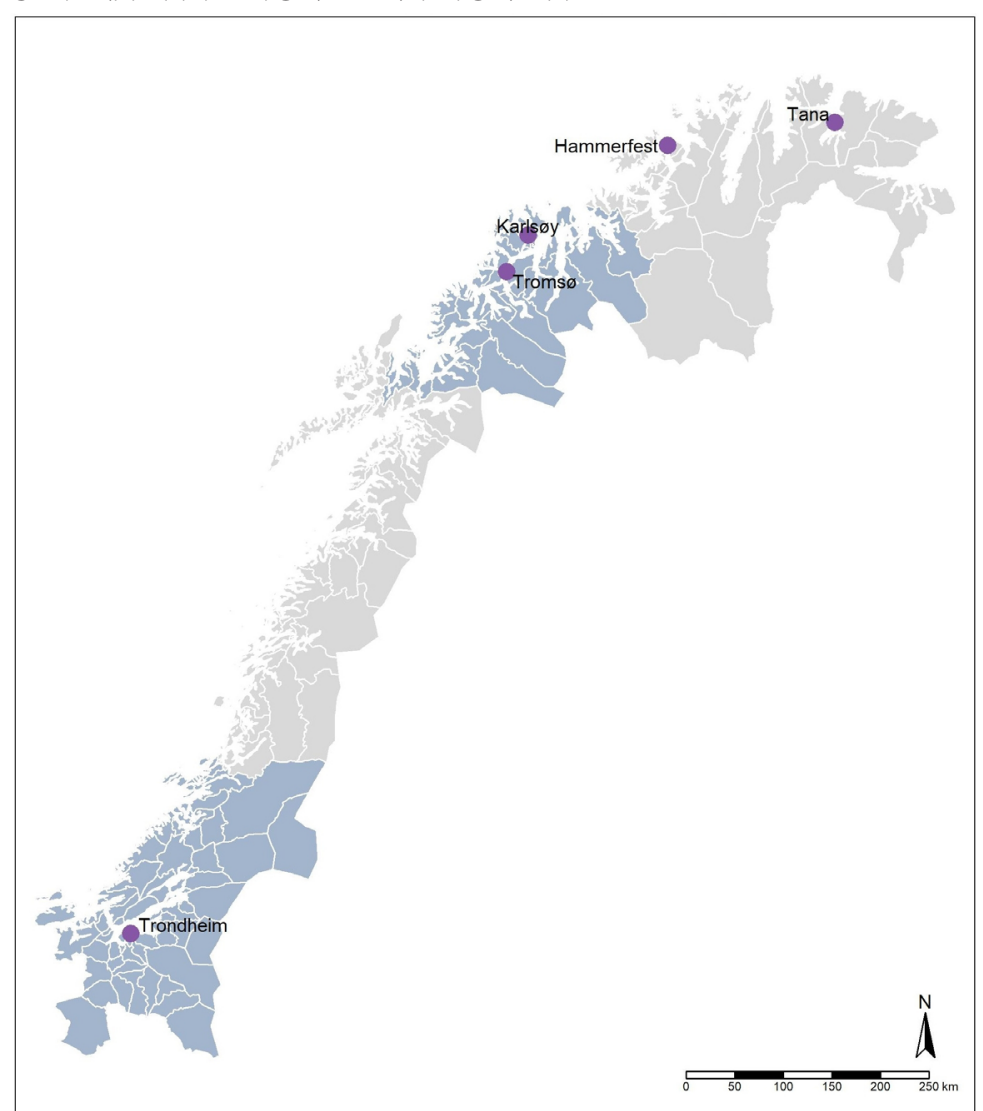

Note: The light blue polygons surrounding Trondheim and Tromsø refer to the province specific studies of Trøndelag and Troms respectively. Other place names refer to the location of parish specific studies. 
The aim of a large cohort study in mid-Norway (Trøndelag) was to contribute knowledge about both the social and geographic mobility of a relatively oversized cohort born in the mid-19th century, by linking individual level data from church books, censuses and the emigration list database of the National Archives. Lindbekk (2017) followed the birth cohort of 4942 persons from 1855 in Trøndelag (plus in-migrants) until the census of 1910, as well as their parents from 1855 to the 1865 census. As in the Troms study, the municipality divisions of 1855 were used throughout. The mobility was studied against a backdrop of individual birthplaces and parental social backgrounds. On the one hand, there was social equality with respect to child mortality and a significant degree of equal social chances and possibilities for migration. On the other hand, the individual operated at the family's own risk, when many young persons had to break up from familiar relationships, occupations and localities in order to seek "permanent and adequate livelihoods" (Lindbekk, 2017).

\subsection{EMIGRATION FROM NORWAY}

Emigration was studied as part of a study of the varied demographic developments in the region of Trøndelag during the period 1866-1914 (Lindbekk \& Opach, 2020), creating comparative municipality maps based on the population censuses. This shows interconnectivity between emigration and internal migration with internal migration as the most extensive. Similar to the national level, the background for mass emigration was the fall in death rates while fertility rates remained stable. Among large, young cohorts only some had prospects for sustainable livelihoods without leaving. Thus, the mobile workforce of young people in search of livelihoods at other places in Norway or America, was a precondition for economic readjustment during the modernizing process.

Rasmus Sunde's doctoral dissertation (2001) about the emigration from Vik parish by the Sognefjord to the US Mid-West is a representative case study about transplanting a specific local European rural population. The dissertation is a quantitative analysis based on reconstructed genealogies of 3319 emigrants, and the database size increases to 12,732 persons when including spouses and children. Using the transcribed church records and the emigration list database of the National Archives with the family reconstitution method, Sunde transformed the genealogical data into measures of demographic behavior - mortality, nuptiality and fertility - which he interprets as indicators of the degree of change in sociocultural behavior after crossing the ocean and meeting new agrarian conditions. In Vik, there was little arable land, and the opportunity to own land was limited by traditional property structures. In America, by contrast, the opportunity to own a larger farm with arable land was available until the end of the 19th century and they could thus achieve greater prosperity. Following Malthus' argument, Sunde suggests that these circumstances in North America would lead to a lower mortality rate, lower age at marriage and higher fertility than among relatives and former neighbors who remained in Vik.

Based on a combination of aggregates and microdata, adding especially hard-to-identify runaway sailors, Eide and Thorvaldsen (2011) summed a total of 960,000 Norwegian emigrants to America during the 19th and first half of the 20th century. We might consider this a reasonable compromise between the old and lower emigration statistics and Mørkhagen's (2009) revised estimate of about a million emigrants in his overview of Norwegian emigration (Thorvaldsen, 2018b). Another disputed under-enumeration issue concerns the US census from 1870: a number of cities at the time complained about under counts. Many estimates for under-enumeration lie around 2-3\%, except for significantly higher proportions in the southern states. Results for Norwegian immigrants in 1870 based on a combination of aggregates, immigration and emigration lists as well as projections of mortality based on microdata, suggest an under-enumeration of about 10\% (Thorvaldsen, 2018b).

Using the linked pairs of censuses from Norway and the USA, a group of economists (Abramitzky, Boustan \& Eriksson, 2012, 2013) published research on the motives behind the emigration from Europe to the USA and "the return to migration" — the economists' expression for whether the emigrants' relocation improved their economy. During the period of mass emigration, the United States maintained a relatively open border for immigrants from many countries, making it feasible to study a migration process less hindered by legal entry restrictions. Using linked data on 50,000 Norwegian men, they studied, on the one hand, the effect of wealth on the probability of internal or international migration in the period 1850-1913. Here, they took advantage of variations in the parents' wealth and in the expected inheritance according to birth order, gender composition of siblings and region of residence. They concluded that relative prosperity made the decision to emigrate less likely in this era, suggesting that the poor might be more likely to relocate if migration restrictions were lifted today, and discussed the implications of such historical discoveries for developing countries. Second, the same researchers 
estimated the extent to which emigration paid off by comparing emigrants from Norway to the United States with brothers who lived in Norway towards the end of the 19th century. The comparison suggests that "the return to emigration" was relatively low and notes that the relatively poor from urban areas emigrated more frequently. Results from the above mentioned Ullensaker project indicate that the latter result does not apply to Norwegian rural areas, although this can be explained by urbanrural differentials and be due to period effects (Koren, 1979). We therefore need further research with longitudinal data to test the economists' conclusions that relative prosperity among Norwegian residents counteracted emigration and that leaving for the US only paid off to a lesser extent.

\subsection{IMMIGRATION TO NORWAY}

Three volumes written in Norwegian cover immigration history comprehensively together with a summary volume in English (Brochmann \& Kjeldstadli, 2008; Kjeldstadli (Ed.), 2003). As part of the first volume, a project analyzed the surnames in the 1801 census as proxies for the missing information about birthplaces in this early nominative enumeration (Sogner \& Thorvaldsen, 2001). The surnames originating in Denmark and the German realm mirror the steadily tighter union between Norway and Denmark with the latter as the dominating partner responsible for an influx of administrators and other specialists to Norway. The German names found in the mining towns of south-eastern Norway recruiting miners from central Europe and in Bergen on the west coast with its Hanseatic trade were also expected, while the significant proportion of foreign names, including Swedish ones in the more isolated Northern Norway was more of a surprise. Naturally, many of these non-patronymic surnames had been inherited over the generations and so only indirectly indicated individual immigrants.

Marta Gjernes (2004) explored the immigration of Jews into the Norwegian capital from 1851 onwards when the constitutional ban on their residence in Norway was amended (the 1814 constitution had blocked Jews' access to the realm). The population censuses were main sources, providing information about both religious affiliation and domicile. Norway together with Canada have long traditions of asking about religious affiliation in their censuses (Thorvaldsen, 2014). During the first 30 years after the opening-up, fewer than 100 Jews settled in the capital Kristiania (Oslo). Her thesis, written to support the Immigration to Norway project, studied the 734 Jews settling or born in the capital from 1851 to 1900. Most were businessmen from Denmark and Germany, and many lived in Kristiania temporarily. With the immigration from Eastern Europe beginning around 1880 the number increased, and by the turn of the century, about 500 Jews had immigrated, the majority of whom settled in in the capital. The eastern European Jews came from small villages in rural areas in the north-western part of the Jewish Pale, the region of allowed settlement in Russia, where they had lived as peddlers, shopkeepers or craftsmen. In Kristiania, commodity trade became the economic niche of the Jewish immigrants, and their residences were clustered ethnically. The Danish and German Jews settled in relatively prosperous areas, while the eastern European Jews tended to settle in a less prosperous area near the city centre, where most Jewish social activities took place. Those established helped newcomers with housing and work. The majority of eastern European Jews started as peddlers, but experienced upward social mobility, both individually and between generations. Few of them became wealthy, the majority ending up in the lower middle class, but could afford their children's education. The children started their careers at a higher level than their parents and settled in more prosperous areas. The flourishing Jewish community came to an end when about 800 persons were deported to the German termination camps while other Jews managed to escape to Sweden.

In summary, internal migration has been studied with cross-sectional and linked data on the individual level, particularly around Oslo, inside Middle and Northern Norway and from the southern to the northern regions. Emigration was already well studied based on aggregates, but from the 1970s onwards trans-transatlantic migration from several localities was analyzed with microdata. Our census microdata assisted the writing of the three-volume immigration history and made possible the study of particular groups of immigrants, such as the Jews. A major finding from individual level studies is that integrated parts of whole societies were transplanted due to the social multiplier effect, both domestically and across the Atlantic. 


\subsection{SOURCES, RATES AND ENVIRONMENT}

Prior to the employment of microdata, Statistics Norway based their studies on historical series of official statistics. In particular they studied mortality, finding that this factor affected population size significantly more than net emigration in most years (Statistics Norway, 1995, table 3.13). During the 18th century, the crude mortality rate fluctuated greatly between 22 and nearly 30 per 1,000. Norwegian historians have disagreed about the relative role of poor harvests and epidemics. In the first half of the 19th century, the variations of the general mortality were less striking, with a crude mortality rate of 18.9 per 1,000 shortly after the Napoleonic Wars, and 17.3 per 1,000 in 1851-1855. During the following hundred years, the general picture has been one of a consistent downward trend although with frequent short-term fluctuations, especially before 1900. About 1900 the crude mortality rate was 14.5 and fifty years later 8.5 per 1,000, a reduction of 41\% (Backer, 1961).

Official infant mortality rates for Norway based on ecclesiastical reports have existed from 1836, but until the 1850 s only at the national level. Based on statistical techniques it has been possible to project rates back to 1735, deriving from available demographic aggregates of births and deaths (McCaa, 1989). Around 1800 an infant mortality rate of around 180 per 1,000 live births is estimated, which by the mid-19th century fell to around 100 per 1,000. As part of the rapid decline in the crude mortality rate witnessed after 1900, infant mortality fell sharply, from around 100 to 22 per 1,000 in 1950 (Backer, 1961). The geographical variation in infant mortality shows a coastal inland pattern, with higher mortality along the coast, as well as a higher mortality in the north, compared with the south (Sommerseth, 2003; Thorvaldsen, 2002). A marked difference between urban and rural infant mortality has also been unmasked (Thorvaldsen, 2002). Official statistics show that the urban mortality rate remained 25-30\% higher than the rural infant mortality throughout the period 1856-1920, both declining slowly at first, and sharply after 1900. From this time the urban and rural infant mortality rate series converged. However, overall urban mortality declined relative to the rural rates from 1920. A central question has been to investigate who paid for the urban penalty and who received the rural reward.

Norway is located in the western and northern part of the Scandinavian Peninsula, and its lengthy topography divides the country into different climatic zones, extending from warm to cold temperate zones, and polar climate in the mountains and the northern regions. In addition, the inland regions have a more continental climate while the coast have milder winters and cooler summers. An illustrative example may be the maximum monthly average temperature of $22.7^{\circ} \mathrm{C}$ (measured in Oslo in July 1901), and the lowest monthly average temperature of $-27.1^{\circ} \mathrm{C}$ (Karasjok in February 1966). Being dependent on the harvest from the soil, fjords and ocean was a yearly risk, and once winter arrived, it affected draughty houses, and the frost lay like a claw until spring arrived. Under such circumstances, the immune system weakens, and the risk of infections increases.

Already from 1820 onwards, the church burial registers included an option to report infectious diseases and accidents specifically. In 1877, it stated that all causes of death had to be registered including information about whether the medical doctor had visited the deceased prior or upon death. The registration of causes of death was part of the medical statistics, provided not only by a priest, but also, from 1853 onward, increasingly by medical professionals. However, around 1860 only about $40 \%$ of all deaths in Norway were represented in the medical profession's reports, increasing to around $80 \%$ in 1900 (Pedersen, 2007). The authorities obviously had an assistant in the local priest, and this gives us a unique insight into long-term trends in causes of death on the individual level.

Well into the 20th century, infectious diseases were significantly more prevalent compared to other cause-of-death groups, and the above-mentioned urban-rural mortality difference has been explained by the fact that the scattered settlement in rural areas has been considered a protective function against the spread of diseases. Conversely, the population density in the cities was accompanied by a greater risk of adverse exposures. Already in the mid-18th century, towns started to monitor the public health, and preventive measures were implemented. For example, the city of Trondheim got the country's first public waterworks in 1777. However, a study based on the burial records for one of its parishes shows that the effect on the crude mortality rate was marginal (Knudtsen, 1997). A more immediate effect, however, was observed with the abolition of the eight days deadline for church baptism, carried out in 1771, allowing parents to have their new-born baptized at home, and not in draughty churches during the winter season (Knudtsen, 1997). 


\subsection{INFANT MORTALITY}

Over the course of the 19th century, the risk was highest in winter for those infants who had survived their first six months of life (Fure, 2002; Sommerseth, 2003). The consequences of generally poor sanitary, hygienic and living conditions are important factors when trying to understand the higher risk the winter season had for the survival chances of the infants.

In addition, the typically short and hectic length of the harvest season could potentially create a sequence of severe risks. Short harvest seasons required all household members to participate, and this was likely a competing activity for women who breastfed new born children. In a study that covers a southwestern parish named Etne and utilizing linked nominative records, it is argued that the peaks in infant mortality are best explained by farmers' wives occasionally reducing breastfeeding due to their participation in seasonal agriculture labour (Dyrvik, 1997). For the coastal women, the amount of work increased with her husband's absence during the large seasonal fisheries, and at times the workload must have been difficult to reconcile with breastfeeding, potentially creating an irregular nutritional practice (Sommerseth, 2006; Thorvaldsen, 2002). Nutritional practice could also be gendered, as shown in the Trondheim case where infant mortality rates from the late 18th century show an unusual excess mortality among boys compared to girls during the neonatal period, which is explained by a culture of favouring the infant boys with a heavy farmer's diet instead of breastmilk (Knudtsen, 1997). In a summary research article about infant mortality in the five Nordic countries, the level and consistency of breastfeeding as well as child care more generally were stressed as decisive factors behind mortality patterns transcending the national borders (Edvinsson, Garðarsdóttir, \& Thorvaldsen, 2008).

During the 18th century, Norway witnessed a social cleavage, when the cotters appeared alongside the dominating social group of farmers. During the 19th century, however, a social levelling-process happened, partly driven by more available land due to mass emigration to the US, but also due to increased demands from a commercialized market which gave the possibility for supplementary income. In Rendalen, a parish located in the southeast of Norway, an extended database version of Sølvi Sogner's family reconstitution was used for several studies. The infant mortality shows the "expected" social gradient, with higher mortality among infants of the lower social class compared to the upper class. During the 19th century, however, these rates converged, probably mirroring the increased importance of timber trade in that area (Sogner, 2000). In Etne, a different picture became apparent, with higher mortality among infants of farmers compared to cotters, but similarly as in Rendalen, the gradient disappeared during the 19th century (Dyrvik, 1997). A study of infant mortality in Asker and Bærum (southwest of Oslo) revealed no significant differences according to social class (Fure, 2000). Clearly, these divergent patterns confirm the complex nature of the causal forces affecting mortality risk.

\subsection{OVERALL MORTALITY AND CAUSES OF DEATH}

If we include all age groups, the mortality patterns do not become clearer. Contradicting McKeown's famous thesis on the relationship between nutrition and mortality, a study based on church records from 44 parishes linked to the 1801 census shows that Norway in the early 1800s had higher mortality among the upper social class compared to the lower social strata (Engelsen, 1983). A possible explanation for this can be found in the socio-geographical pattern typical for parts of Norway, where the poorest often lived on a small cotter's place in the periphery of the main farm, and the wealthiest lived more centrally in so-called "klyngetun" [cluster yards - not to be understood as villages], where the farm's houses, as the concept suggests, stood close together. Consequently, the exposure to infectious diseases was higher in the social upper class and to such an extent that it resulted in their higher mortality (Engelsen, 1983). Other studies have, on the other hand, emphasized that the centerperiphery (or urban-rural) dichotomy may miss the dynamic and seasonal shift in settlement patterns. This is often found along the coast where seasonal migration was enormous during the big seasonal fisheries, and thus could potentially create regular surges of infectious diseases for a short period in typical rural areas (Sommerseth, 2003).

Cold and wet autumn and winter months were also a risk for the whole population. The disease environment in Trondheim city during the last part of the 19th century was dominated by airborne infectious diseases, with pneumonia and bronchitis as two of the largest cause-of-death groups. Airborne diseases killed nearly $60 \%$ of those children who died, and was the main killer for ages 1 to 49 in a study of 19th century Trondheim burial records (Sommerseth \& Walhout, 2019). Poor and crowded housing, deficient sanitary and hygienic conditions, also contributed to high tuberculosis (TB) 
mortality. Placed in the national context of relatively high TB mortality, a recent study based on church records takes a closer look at age and sex differences, as well as societal and spatial TB inequalities in Tromsø during the years 1875 to 1920 . The results, though not statistically significant (probably due to small numbers), show the expected female excess mortality, and women aged 15-49 were the most exposed. Interestingly, the study also finds higher mortality among the working class, and in areas where dwelling quality and overcrowding was an issue, women were particularly vulnerable. One explanation for this pattern could be that women (and children) spent more time inside these dwellings than men who spent long working days elsewhere (Kovacevic, 2020).

Traditionally, the 1918 flu pandemic was perceived as socially neutral. However, Mamelund (2006) showed how it affected the lower social classes more severely, leading to higher death rates. His results are based on burial records linked on the individual level to annual city censuses. By comparing two socially contrasting parishes in Kristiana (Oslo), namely Frogner and Grønland-Wexels, he found that apartment size (which was an ideal proxy for rent $(r=0.98)$ and therefore deemed a good proxy for income), was negatively and significantly associated with mortality. All other factors being the same, his results showed a $49 \%$ higher mortality rate for those residing in the poor parish of GrønlandWexels compared with the affluent parish of Frogner.

\subsection{MORTALITY AND ETHNICITY}

In an ethnic context, studies show higher infant mortality among Sami nomads compared to other ethnic groups, and one explanation for this may be the strains of moving between summer and winter grazing (Andresen, A. 2001). This explanation is also in line with studies of infant mortality in Jokkmokk (Sweden) where the high infant mortality among Sami nomads coincided with the most intense work period on summer pasture (Brändström, 1988). Based on linked church records, results from the sea Sami area of Tana in Finnmark did, on the other hand, not find a significant mortality difference between infants born by Sami compared to those born by Norwegians. This strengthens the explanation that the high infant mortality found among the Sami nomads, was likely a consequence of neglected care due to periodically severe working conditions for women who just recently had given birth, and not driven by ethnicity as a strict biological measure (Sommerseth, 2003, 2006). The same study found higher infant mortality among the Kvens (Finnish immigrants). Studies that cover the historical population of northern Finland explain the high infant mortality (20-40\%) with artificial nutrition - usually fresh or sour milk (Brändström, 1988; Lithell, 1988; Pitkänen, 1983). An obvious assumption is therefore that some Kvens brought with them a cultural nutritional practice when they migrated to Norway (Sommerseth, 2006). The Kven migration to Tana in Finnmark took place mainly from the middle of the 19th century, and we can clearly see how the trend over time shows a declining mortality from a relatively high level during the first years of settlement, to a level similar to the Sami and Norwegians one or two generations later.

According to Sunde's family reconstitution (2001), the first generation of immigrants to the US MidWest were faced with a process of acculturation, and this in combination with a more fragile social and kin network, different nature and climate, family households met new challenges, some for better and others for worse. During the settlement process children were born, and it is reasonable to assume that infants of the first-generation immigrants were exposed to a higher risk just by being born during a process of securing permanent footing in a new country. This assumption is supported by studies done on Norwegian immigrants in the USA, where the first generation of immigrants experienced a higher risk of losing a child before the age of one.

\subsection{EXPLAINING THE INFANT MORTALITY DIFFERENTIALS}

In Norwegian historiography, there are various explanations for the relatively high 18th and early 19th century infant mortality, its comparatively low level in a European context, and its trend over time, which was characterized by a steady decline in the 19th century and a sharp decline in the 20th century. There is a broad agreement that public health measures in the 19th century through vaccination programs, a focus on stillbirths, introduction of educating midwives in 1810, appointment of district physicians and establishment of health commissions (an urban phenomenon from 1803, but fully incorporated in all municipalities of the country from the 1860s), were all conditions that stimulated a low mortality level (Sogner, 2000). On the other hand, what caused the initial fall in infant mortality has been questioned. For example, the work of doctors and midwives may or may not have been pivotal for the early phase of the decline in infant mortality, since the decline began long before 
the districts had their own doctor and midwife (Dyrvik, 1997; Fure, 2002). As demonstrated in a study of infant mortality in Hammerfest town utilizing the ministerial records, it is likely that education and presence of a health care system resulted in an earlier and more beneficial effect in urban compared to rural areas where in the latter case a couple of doctors and a midwife had to cover vast distances (Mølmann, 2004).

The ethnic dimension is also important when we examine the potentially beneficial effects of health care measures. With increased forces from the late 19th century, Norway executed an offensive policy towards the Sami population and later the Kven population in the so-called Norwegianization process that sought complete assimilation. The northernmost and ethnically mixed county of Norway, experienced one of the highest infant mortality levels compared to other counties and is today faced with the highest crude death rate. Questions remain about the long-term trend and potentially continuing health effect of the Norwegianization process. One explanation is the long-term effects of sub-standard living conditions during childhood and adolescence (Forsdahl, 1973).

In recent decades, studies concerning the reproduction of health advantages and disadvantages across generations have flourished. One study that prepared the ground for further research in Norway, showed an important turning-point with improved life expectancy among women already from the 1770s, while it took more than 80 years before men started to catch up with women (Mamelund, 2001). Again employing her Rendalen database, Sogner (2000) who already then was acquainted with Mamelund's results, argued that the improvements in women's health and life expectancy had a beneficial effect on their infants. She further argued that the difference in life expectancy between men and women was a result of the introduction of commercialized forestry on a large scale from the 1790s. This meant rougher living conditions especially for men. However, women, who in general were not employed in forestry, may have profited indirectly from the new sources of family income, beneficial to a healthier lifestyle and thereby improved survival of their infants.

To what extent a mother's health matters has also been questioned by looking at the living conditions when a mother was born and the possible effects on the survival of her children. In other words, were mothers born in difficult years imprinted by the adverse conditions so that when giving birth, their infants had an increased risk of dying? Good and bad periods were defined by using levels of high and low infant mortality, and the results showed that the neonatal mortality was twice as high for infants whose mothers were born in years with high infant mortality. After the neonatal period, there were no mortality differences according to mothers' birth year. A possible explanation is that some of these mothers themselves were born under adverse conditions, caused by disease or undernourishment, in utero or in early infancy. They might have been predisposed to bear weaker infants (Fure, 2002). This transgenerational programming may have happened epigenetically, as changes in the gene expression system that can be inherited from mother to child (Bygren et al., 2014). Along with increased access to longitudinal data that covers multiple generations, we are now in a position where these questions can be given robust answers, also in an international and comparative fashion.

The international Intermediate Data Structure (IDS) format was applied in a comparative study of intergenerational inequality in infant mortality, in which research teams from the Netherlands, Belgium, Sweden and Norway participated with their respective datasets. In the first part of the project, separate analyses were carried out, but with a common theoretical and methodological design. The results from linked ministerial and census records in the Historical Population Register for Troms province in Norway, show that there was a transmission between the generations with respect to risk of experiencing infant deaths. A woman's children were at greater risk of dying before the first birthday if their grandmother had had several infant deaths. The risk of infant death among children of daughters from such highrisk families was at least 30\% higher than among infants born to the daughters of mothers who had experienced zero dead infants. At the opposite end, we find the majority, where $60-70 \%$ of families across generations, never experienced the loss of any infant (Sommerseth, 2018). Similar findings were also made in the analyses of the other countries, and overall, these findings point in the direction of a different understanding of how mortality risks varied among the very young (Quaranta \& Sommerseth, 2018). Infant mortality in historical populations did not affect every house and family. The next step in the project has been to assemble all the countries' datasets into a common database and carry out a common statistical analysis. The results confirm findings from the first round and represent a pioneering work for further internationalization and comparative historical demography (Quaranta et al., 2017). 
In sum, Norwegian mortality studies have focused on rural-urban differences and infant mortality, using the rich collection of transcribed vital records from the church books. Recent historiography especially dealt with long-term influences over three generations from grandmothers to grandchildren and how trauma in the mothers' early life could influence the survivability of their small children. Other studies deal with the situation of the ethnic minorities and the migrants.

The nuptiality studies have focused on the timing of marriage relative to the transfer of property between the generations, illegitimacy and intermarriage between the ethnic groups.

\subsection{MARRIAGE MARKETS AND TIMING OF MARRIAGE}

The effect of shifting generations and mortality levels was the topic of Hans Henrik Bull's dissertation on nuptiality, presenting a long-term study of social homogamy, timing of marriage and illegitimacy. This is yet another project researching rural Rendalen close to the Swedish border in the 18th and 19th centuries (Bull, 2005, 2006) building on Sølvi Sogner's database with longitudinal information (Gjelseth, 2000). Prior to 1870, the occupation of parents was to a varying degree recorded in the Norwegian parish registers, but can usually be found in the censuses. Structural changes over time, which led to an increase in the number of farm workers, reduced the degree of homogamy among farmers, and extended the marriage market for farm workers, thereby increasing homogamy among the latter group. Controlling for these structural changes, it is clear that social boundaries between farmers and farm workers prevailed at least until the end of the 19th century. Multivariate analysis identified family characteristics that led young men and women to marry homogenously. The farmers, especially, exerted influence on their eldest sons to marry farmers' daughters, but the role of the father in the mating process also secured economically viable partners for the other siblings.

Furthermore, Bull's dissertation analysed the connection between inheritance and the timing of marriage as well as the development of illegitimacy rates in the same rural stem-family community. In pre-industrial Europe, access to a livelihood, whether on the family farm or other means of earning a living, was considered a prerequisite to marriage, usually through intergenerational transfer, which, especially in the 18th century was affected by the level of adult mortality. Early mortality among adults created opportunities to marry a widow(er), and for a farmer's eldest son to take over the farm. In the 19th century, a reduction in adult mortality and the subsequent rate of remarriage closed this opportunity. However, the timing of marriage was less affected by the intergenerational transfer of wealth than by the family's ability to use the work force of men and women. Thus, the amount of wealth a woman brought into the marriage might be valued less than her ability to work and run a household.

In the second half of the 18th century, the number of illegitimate births increased in Europe, while the number fell a century later. Bull's dissertation examines premarital sexuality and marriage in the Rendalen database between 1750 and 1900. A new measure of premarital sexuality, called the extramarital pregnancy rate, includes children born out of wedlock as well as children born to pregnant brides. The study shows that both among the daughters of farmers and of farm workers there was a clear increase in extramaritally conceived children at the end of the 18th century. This was caused by a development whereby the choice of partner was now made based on mutual attraction rather than economic strategies. The fall in illegitimacy at the end of the 19th century was likely connected to the bourgeoisie family's more puritan view of female sexuality spreading among the farmers, thus distancing themselves from the group of farm workers, and once more strengthening their control over the children's marriages in the second half of the 19th century (Bull, 2005, 2006).

\subsection{NUPTIALITY AND ETHNICITY}

Ethnic marriage patterns were studied in two parishes north of Tromsø from 1770 to 1900 (Larsen, 2008). Microdata and aggregates from the church records and censuses were used to define ethnically homogeneous and mixed areas, in order to compare their demographic developments with individual level data. From 1845, the Norwegian censuses contain ethnicity information, usually denoted as 
nationality, primarily to enumerate the Sami and Finnish minorities. When the censuses became nominative in 1865, ancestry and belonging to an ethnic group were the main criteria, but towards the end of the century, individual and cultural criteria like language became more central. The interpretation of the ethnic markers are not always straightforward, for instance the ethnonym "Fin " can mean Sami in some censuses and Finnish in others, but as a rule close inspection of the nominative manuscripts reveal the correct interpretation (Thorvaldsen, 2018a, p. 138).

The phrase "meeting-place of the three tribes" has been coined to describe the ethnic composition of the two northernmost provinces in Norway. This is a reference to the mixed ethnicity of the region with people of Sami, Norwegian and Finnish heritage. While it is contested which areas were traditionally Sami, however, there is no doubt that Norwegians took over large areas formerly used by the Sami. Thus, the Norwegians spread from the south towards the north and from the coast towards the inland. The Finnish immigration from Sweden and Finland started in the 18th century but gained real momentum from the 1830 's. The 1865 and 1875 censuses show that $13 \%$ of the population in Troms province was Sami, while 5-7\% were of Finnish stock, proportions decreasing to 9\% (Sami) and $2 \%$ (Finnish) in the 1900 census. Concurrently, the ethnically mixed population grew from $3 \%$ to $9 \%$. Research confirms that the censuses render ancestral ethnic heritage quite correctly, so these figures mirror the intermarriage of the ethnic groups. Mixed marriage between the Norwegian and the Sami group was relatively infrequent, while the Finns married both Sami and Norwegian partners, functioning as a catalyst in the ethnic salad bowl. However, even if individual members of the three ethnic groups could be on good terms, there are numerous reports about conflicts, especially between Sami nomads and Norwegian farmers.

As expected, almost all women in the two parishes north of Tromsø married and most of them very young around 1800, as they did in other Sami-dominated areas. This pattern disappeared early in the 19th century, perhaps due to economic pressure. Geographical boundaries increasingly constituted ethnic boundaries, and marriage contact between the parishes became infrequent, especially between the Sami population groups and particularly after 1880. The demographic developments in the parishes were different, with respect to marriage age, proportion unmarried, remarriage frequency and population stagnation or expansion. A stricter ethnic hierarchy, discriminating the Sami, caused gender imbalance and thus lowered the marriage rate in one of the parishes. This is the likely cause of increased illegitimacy outside of the area with strict Laestadian religiosity. The Laestadians, while still members of the State Church, attempted to regulate all aspects of their adherents' lives. Laestadianism also counteracted some of the discrimination of the Sami. In the population exposed to Norwegianisation, Sami ethnicity tended to dominate and influence the spouse. This may be because the ethnically mixed population here had no choice but to stick to the Sami identity (Larsen, 2008).

Nuptiality has been analyzed in selected localities. To sum up, in the south-east, marriage was connected to the transfer of property and there was a development from arranged marriages to selfselected partners in the early 19th century, concurrent with a rise in the number of illegitimate births. In another highlight from the north, "the meeting place of three tribes", there were more restrictions on marriage between the Sami and the Norwegians than on the Sami marrying immigrants from Finland. The two latter groups were able to combine access to land with agricultural experience, while the two former groups often had conflicts about using land for traditional reindeer pasture or agriculture.

\section{FERTILITY}

\subsection{PATTERNS OF DECLINE}

Influenced by the Princeton project (Coale, Anderson, \& Härm, 1979), Sogner, Fure and Randsborg (1984) mapped the Norwegian fertility patterns both on the regional and municipal levels. Based on official statistics, their results point to a fertility increase in the period 1801-1835, a stable high fertility in the period 1835-1900 and a fertility decline starting around 1890. Moreover, this nationwide study suggests that the spread of birth control had both a social and geographical gradient, starting among couples in the higher social classes in urban environments (Sogner et al., 1984). In the following we shall refer to studies that used family reconstitution primarily based on church books and censuses, where fertility behavior within the boundaries of a parish or municipality have provided us with a more nuanced picture of the diffusion theory proposed above. 
Generally, both marriage and fertility - two closely related phenomena in historical populations with limited access to contraception - were positively correlated with social status and wealth. With easy access to a livelihood, the earlier the marriage, the more children born. Consequently, for the rural areas in Norway, peasant women had a lower age at marriage and higher age-specific fertility compared to the cotter women (Sogner, 1979). In the pre-transitional phase, accompanied by an overall rapid population growth, Norwegian society underwent radical economic and social changes, with a strong development in the secondary and tertiary economic sectors both in rural and urban areas, growth in the number of cities and suburban areas, increased internal migration, all pointing to a complex web of driving forces behind the fertility transition phase. Undoubtedly, major societal changes affected demographic behavior, and as have been demonstrated in several master theses conducted on the parish level, the abovementioned social and geographic gradient have numerous exceptions. For instance, there was a relatively higher age at marriage and low fertility among peasant women in Norddal and Rendalen (Linge, 1977; Sogner, 1979); equal fertility levels between peasants and cotters in Ullensaker and Bø in the region of Telemark (Halvorsen \& Indseth, 1875; Randsborg, 1979), while the decline started first among the lower social classes (cotters and farm laborers) in Kolbu (Fure, 1980). A positive correlation between fertility and social status was on the other hand found in the cities Christiania (Oslo), Bergen and Trondheim. "Own children" rates calculated from the 1801 and 1875 censuses indicate that fertility was somewhat higher in the upper than in the middle and lower social strata. For the latter two groups, fertility was virtually identical (Sogner et al., 1984)

A contradicting result was found in the city of Stavanger. Based on a random sample of 609 families drawn from the censuses of 1920 and 1930 linked to demographic data from church books and the city population register, Dyrvik and Alsvik (1987) studied the introduction of birth control during the first decades of the 20th century. Their analysis showed no connection between birth control and occupation, income or standard of housing. Fertility decline started in the humble quarters of Stavanger, but accelerated in more affluent sections. The adoption of fertility regulation differentiated most notably between the trades, the living quarters and the parental birthplaces. This indicates that the innovation spread through a hierarchy of communities, using a communication network defined by cultures and subcultures.

\subsection{ILLEGITIMACY}

So far, we have focused on the fertility behavior within marital unions. Left out are the illegitimate births. Around the beginning of the 19th century, regional numbers show that between 2 and 10 out of 100 births were registered as illegitimate, and our narrative would be deficient if we excluded them. Based on church books from Moss town covering the years 1776-1825, Eliassen found an increase in illegitimate births from $10 \%$ in 1780 s to $15 \%$ during the first decades of the 19th century (Eliassen, 1981). Comparing the increase with the concurrently declining proportion of marriages, two distinct marriage strategies were detected. During the first period, until 1800, marriages were postponed. During the first decades of the 19th century, however, illegitimate births to a lesser extent led to marriage. It also varied to what degree different priests let the prospect of marriage influence notions about legitimacy.

In her master thesis, Haavet (1982) examined the social status of unmarried parents before and after an illegitimate birth. Her study is based on 44 parish record books covering the years 1795-1800 and 1802-1803, linked to social status in the 1801 census (cf. section 2.1). Relative to different social classes in the unmarried population, there were slightly more servants who gave birth to illegitimate children. Unmarried parents who were registered as living as single in their childhood home, had on average occupations with a lower social status than the general population. This was especially true for the mothers, while the distribution for the fathers was more even. The thesis concluded that there was little evidence pointing in the direction that unmarried parents were punished for their premarital intercourse, for example by being defined as outcasts after an illegitimate birth. On the other hand, if the illegitimate birth did not lead to marriage (although it often did), the chances of a later marriage to someone else were highly skewed by gender. Perhaps not surprising, unmarried fathers later on had a marriage frequency that seems unaffected by an illegitimate child, while single mothers were handicapped in the marriage market.

The fertility decline, in summary, started in the higher urban social classes and was slowest in the peripheral, agricultural environments. Results from local reconstitution studies are, however, more nuanced, indicating that the fertility transition was a cultural phenomenon which spread through a 
hierarchy of communities. Illegitimacy rates varied throughout the country, a result of mating cultures that could be tolerated locally to varying degrees, and priests who often modified their classification of illegitimacy if they were positive that the parents intended to marry.

\section{FAMILY HISTORY}

\subsection{INTERGENERATIONAL CO-RESIDENCE}

The prevailing discourse on family history since the early 1970s has downplayed earlier assumptions that industrialization and urbanization diminished intergenerational co-residence. Accordingly, the dominant form of household structure in Western Europe and the United States in pre-industrial times was nuclear, and industrialization did not change the structure of domestic life. A typical life cycle pattern is one where elderly parents gradually moved into one of their children's households when they were no longer able to keep an independent household. Norwegian scholars have largely confirmed the dominance of nuclear households in pre-industrial times, with studies emphasizing the economic role of the household as a unit of production and consumption around the nucleus of the 18th and 19th century farmers, cotters, and fishermen households (Bull, 2000; Dyrvik, 1993; Fure, 1986; Sogner, 1978, 1990; Solli, 1995). Moreover, the majority of these studies found that occupations connected to owning property (mostly farmers) were associated with an increase in stemfamilies compared to landless cotters, and thus became a focal point in studies on the connection between land ownership and extended family household formations in the Norwegian pre-industrial context. The allodium law and residing (åsetes) right played a crucial role in maintaining a stem family system in Norway, however strongly associated with a sustenance economy.

In addition to stating that the oldest son should inherit the farm (primogeniture), allodium law described a set of rights that the older generation had upon retirement and the transfer of the farm. After moving out from the main building into a separate house ("kårhus"), the older generation could claim a part of the farm's livelihood to provide security during their old age. Thus, among family historians, the allodium law and the retirement contract accompanying it have been seen as strong evidence for a consistent and culturally homogeneous family system across pre-industrial Norway. Sogner suggested that the strong influence that laws of inheritance and land transfer had on people's choice of living arrangement met its end during the 19th century, when competitive alternatives arose. New possibilities were migration to America and Northern Norway, and to new occupation alternatives in the towns (Sogner, 2009).

\subsection{FRAGMENTATION OF THE HOUSEHOLD STRUCTURE}

In his dissertation on the history of the household, Solli (2004) investigated three related research questions: To what extent did household and life cycle patterns change during the 19th century? In what way did this change, and why? The empirical and methodological focus was on the life course leading up to the establishment of households and the defining marriage, and the sources were the full-count, nominative 1801, 1865 and 1900 censuses used cross-sectionally. The initial analysis on the national level identified typical life cycles, household characteristics and a range of social, political, economic, cultural and demographic explanatory variables. These explanatory variables were tested against the life cycle and household patterns, suggesting three sub periods: until ca. 1840, 1840-1870 and 1870-1920. The first phase was characterized by a stable supply of land resources being the sine qua non for household establishment, such as the northwestern European household system outlined by Hajnal (1965). However, wars and crises together with increased demand for Norwegian exports led to a somewhat higher number of varied livelihoods. Major changes in the resource base, for example more extensive herring fisheries, facilitated the splitting of some farms into peasants and cotters' smallholdings.

The second phase, ca. 1840-1870, was more adaptive, with marriage becoming less contingent on a stable livelihood. The pressure on the household structure was both demographic and economic with population growth and expansion of trade and commodity production. Along the coast, the population grew rapidly, based on shipping, trading and fishing. However, the growth did not lead to major changes in the household structure; people settled traditionally by increasing the number of smallholdings and families resulting in an average of five to six persons. However, the adaptation 
was different where cattle and grain production dominated. In mountainous parts, the population increased less, in some areas it even declined or stagnated. Siblings and the retired ("kårfolk") more often established their own households, and the former established themselves with the few new types of livelihoods such as teachers, shopkeepers, day-workers, with incomes often too small to feed an entire family. Thus, in the uplands, the traditional household structure was destroyed during this period. In spite of industrial growth, the urban changes in household structure were confusingly similar to the changes in mountainous Norway. A starting fragmentation of the household structure characterized both, with more single persons in all age groups, especially the young (20-29) and old (over 60). Also, more women of 45 years and older became household heads, resulting in more production-free livelihoods that were less dependent on a married couple. Instead, working in the expanding trades after the economic liberalization of the 1840s became an increased opportunity. Changes in the rural flatland communities in eastern and mid Norway were less significant. Male servants still contributed heavily to the work force and were often part of the farm household. Thus, rationalization and specialization in agriculture influenced life cycle and household structures relatively little, maintaining the sharp social differences.

In the third phase (ca. 1870-1900), the relocation of social production out of the household to the more heterogeneous secondary and tertiary sectors became extensive, changing the life cycle and household structure significantly in most of the country. Young single men were main players in the waged labor market, while women were main characters in the households. The larger the secondary sector, the lower the age at marriage and establishment, the longer the children were raised at home and in schools, the smaller the household size and the more people were single. Thus, the third period was characterized by a quantitative socio-economic and demographic shift with more production-less households established in densely populated areas (Solli, 2004). With hindsight, we must conclude that Hajnal's theory of typical and interrelated household markers, fit the Norwegian reality better at the start than at the end of the period studied (Szołtysek, Ogórek, \& Gruber, 2021).

The inheritance practice described above assumes a life change for the older generation. Sommerseth (2011a) has explored family living arrangements from the perspective of the elderly and their coresiding behaviour with an own adult child in Northern Norway during the last part of the 19th century based on the 1865, 1875 and 1900 censuses. As stated by Ruggles, this perspective has an additional advantage: it controls for demographic conditions and constraints typically found in historical populations of the western part of the world. Late age at marriage, combined with no deliberate fertility limitation, resulted in generations tending to be long (Ruggles, 1994). In addition, the combination of long generations and relatively short life expectancy reduced the potential number of years it was theoretically possible for adult children to live with their parents. Furthermore, since married brothers and sisters seldom resided together, although the relatively high fertility resulted in family living arrangements that extended beyond the nuclear form, these would always be in the minority.

\subsection{ETHNICITY AND DECLINE IN INTERGENERATIONAL CO-RESIDENCE}

A case study of Northern Norway was also needed to test the narrative of a culturally homogeneous Norwegian stem family system. Pre-industrial Norway was not culturally homogeneous. Northern Norway's population consisted, and still consists of three different ethnic groups: Sami, Norwegian, and Kvens. Contrary to primogeniture, an alternative common cultural practice existed among the Nomadic Sami as well as among the Coastal Sami population, an ultimogeniture inheritance practice. This means preference was given to the youngest child — preferably to a boy - when property was transferred between generations. The youngest child then provided for his or her parents throughout their lives. The presence of two different inheritance practices within the same geographical area gave a unique opportunity to compare the effect such practices had on living arrangements for a population that shared similar ecological and economic opportunities.

It is well known that in a pre-industrial economic system, intergenerational living arrangements were beneficial both to the older and to the younger generation. Among farmers and fishing farmers, two adult generations in the household meant that capacity for labour-intensive work was ensured. Conversely, in fishing households, the working crew was often organized across the household boundaries. Young sons went out early to participate in the fisheries, and this gave independence in the form of having their own income. In addition to this, the ocean was part of the commons; one could not inherit access to fish there. 
By the close of the 19th century, less than half of all elderly people (60+) resided with an own adult child (18+) compared with approximately $60-65 \% 35$ years earlier. Intergenerational co-residence was positively associated with being a married Sami male with an occupation in farming or combined fishing and farming (Sommerseth, 2011a). It is argued that ethnicity played a role; however, its effect disappeared after controlling for economic activity.

The change in intergenerational co-residence was primarily characterized by a decline in the number of married sons staying in their parental homes, and the decline was persistent in all economic sectors. What we see is an increase in widowed and dependent elderly people living as lodgers in households of supposedly non-relatives. Just as the inheritance practice may have expressed an ethnic practice in 1865 and 1875, its articulation was less visible in 1900 (Sommerseth, 2011b). It is further argued that the decline in intergenerational co-residence between 1875 and 1900 may be explained by young men's increased opportunities to take on different occupations, and for some this may have been more attractive than staying at home. Irrespective of the father's marital status, the majority of children living with their elderly fathers were sons. Secondly, we know that the Norwegian state increased its efforts to assimilate the Sami population into Norwegian law and culture. Along with this assimilation process, we also see an increased interaction in the private sphere, for example inter-ethnic marriages. Thus, as ethnic differences in intergenerational co-residence had disappeared in 1900, the consequence was an approach towards a similar family system for the Sami and the Norwegian population.

For one single multi-ethnic parish in Northern Norway census data formed the basis for a longitudinal approach to investigate further son preference. Based on father's complete fertility history, and controlled for any child loss, the study asked if a son preference merely was a consequence of inheritance practice, such as co-residing with first-born son. Although the sample was small, few indications supported this. Again, sons were preferred. The analysis suggests that one important reason is the masculine character of the fisheries, where the transfer of knowledge from father to son was crucial for successful economic results, thus promoting masculine obligations across generations, strong enough to have a significant effect upon living arrangements, irrespectively of ethnic affiliation (Sommerseth \& Thorvaldsen, 2016).

As a generalization, these studies confirm the dominance of nuclear households even in pre-industrial times, emphasizing the economic role of the household. In addition to prescribing male primogeniture, the allodium law prescribed rights to housing and subsistence for the older generation upon retirement. A gradual development from the 18th to the 20th century was first characterized by slow population growth and a stable supply of land resources being a necessary condition for household establishment. Exports and rich fisheries in the 19th century with accelerating population growth enabled the establishment of new households based on livelihoods outside agriculture. Next, the period from ca 1870 was characterized by a larger socio-economic and demographic shift with more production-less and smaller households dominated by women in densely populated areas. In Northern Norway, there was a tendency for single fathers to live with a son, facilitating the transfer of occupational skills over the generations.

\section{A NATIONAL HISTORICAL POPULATION REGISTER (HPR)}

The already mentioned grant from the Norwegian Research Council (see section 2.2) accelerated the creation of the Historical Population Register of Norway, covering the whole period from 1800 onwards and connecting with the modern population register, which was introduced in 1964 . The historical population register combines microdata into an integrated database with two main objectives. It documents, formats and provides historical personal records covering an increasingly large part of the country at the disposal of researchers, ultimately expanding it to a national and longitudinal register for the last couple of centuries. This interconnection of different sources at the individual level provides new sources for critical insights (Thorvaldsen, 2011).

The HPR places Norway at a vantage point in terms of research on a wide range of questions about the historical development of the population which forms the background for contemporary conditions. Due to the lack of readily available individual level data, in particular the mid-20th century is an understudied period in our population history despite the crucial demographic changes, such as declining fertility and mortality and the post-war baby boom. Other examples with a wider timeframe include changes in family structure, changing migration flows domestically and across the borders and 
a revised personal name culture. The possibility of linking such a historical register against the current Central Population Register opens unique opportunities for research on contemporary demographic phenomena with a historical perspective. This is particularly important when inter-generational processes are central, as with social and regional mobility, education and career choices. For researchers in the field of medicine, psychiatry and public health, the possibility of following family relationships over many generations will be a valuable source for studying the heredity of diseases and disorders. As outlined above, Sommerseth has used the HPR to demonstrate transmission of levels of infant mortality between generations.

For legal and ethical reasons, see section 2.2, the HPR must be in two parts. Until the 1920s, most of the information is available to everyone via the Internet and thus a popular offer to local historians, genealogists and locally oriented teaching. Information from the period after the 1920s will be reserved for researchers upon application and ethical vetting. The full count censuses up to 1910 are already made available by means of data processing, and the full count 1920 census will be public on the Internet by early 2022. It is, however, uncertain to what degree we can reconstruct the numerical censuses from 1815 to 1855 at the individual level with nominative data from the HPR. The first version of the 1950 census has been transcribed with machine learning techniques and an improved version will be available for selected researchers in 2022, while work on the 1930 census has started. The baptismal lists can be used until 1930, and data on burials and marriages are in principle open until today, and these church records have been transcribed until the mid-20th century. Statistics Norway has already digitized the censuses since 1960. The censuses since 1910 contain birthdates, facilitating record linkage with data from other sources. Many baptismal, wedding and confirmation lists from the 1800s contain birthdates, and when we shall have certified their quality, they will be linked to the 20th century censuses. Much of this work is automated, because we have access to lists of standardized names; and in addition to this, genealogists contribute with links through the website Histreg (https:// histreg.no). The census aggregates can also be used to assess the representativeness of researchers' extracts from the Population Register.

We cannot satisfy all potential users of the Historical Population Register with one and the same user interface. The Intermediate Data Structure (IDS) addresses the needs of statistically oriented users who have a source-critical attitude to all the events about a person (Alter \& Mandemakers, 2014), but require users to be more computer literate than the average historian - necessary support services are not sufficiently available. Histreg's web pages serve the needs of those who want to browse pedigrees of their ancestors and make it possible to edit contents based on genealogists' expertise. However, it is up to the users to produce representative statistical results without special support. This is somewhat easier in NHDC's Timeline system because cohorts can be constructed quite flexibly, but that system is designed to track the life courses of individuals rather than following large groups of people (Thorvaldsen, Sommerseth, \& Holden, 2020). The North Atlantic Population Project (NAPP) files with linked censuses include weights that allow adjustment of statistical biases in the linked files, but only cover two moments in the life cycle (see https://international.ipums.org/international/linked_ data_details.shtml). Since most baptismal records contain dates of birth, these can also be linked to the 1910 census and to later censuses. The census from 1950 is linked to the central population register from 1964 as part of the transcription process. We are also inspired by the interfaces developed by our sister institutions in Umeå, Lund, Amsterdam, Salt Lake City and Chicoutimi for future solutions.

Computer algorithms for record linkage and the encoding of family relations have been created both at UiT The Arctic University of Norway and the Norwegian Computing Center. The record linkage algorithms are based on similarities in names, birth year, birthplace, occupation, address and relations with family members. In addition, we also check that the events make up a reasonable life course. The algorithms must be adapted to the characteristics of each source in order to keep the error rates low. For example, it is necessary to require stronger similarities for large municipalities such as Oslo, than for smaller municipalities where fewer persons share equal identities.

The main responsibility for the project is UiT The Arctic University of Norway c/o the Norwegian Historical Data Centre (NHDC). Partners in Norway are the Norwegian Archives, Statistics Norway, the Norwegian Computing Centre, the Norwegian Local History Institute, the National Institute of Public Health, Norwegian School of Economics $(\mathrm{NHH})$ and the University of Bergen.

In summary, the Research Council of Norway has granted resources for the establishment of a national, Historical Population Register (HPR), covering the period from 1800 until the modern, 
Central Population Register takes over from 1964. The HPR links censuses and vital records etc. in a common database with the main aim to expand it to a national, historical and longitudinal register for researching social and population history during the last couple of centuries. Also, the merging of different sources at the individual level provides new source-critical insights.

\section{SUMMARY AND CONCLUSION}

The microdata versions of Norwegian historical individual level sources have allowed a wide range of topics within population and social history to be studied more extensively and in more detail. Previously, most publications were either local community studies or using aggregates open to the well-known fallacies. Now, we have a wide range of topics in doctoral dissertations, master theses and articles, and the variety can be illustrated with some examples:

- Infant mortality in Asker and Bærum in the late 18th and early 19th centuries and in multi-ethnic Tana parish from 1840 until World War I.

- Family history in northernmost Norway towards the end of the 19th century and about family structure in 18th century Rendalen.

- How the Spanish flu affected high and low socio-economic groups in Oslo differentially.

- Operationalizing a model for the timing of marriage and illegitimacy in Rendalen, 1750-1900.

- Changes in family structures on the national level using the censuses through the 19th century.

- On migration in Rendalen and south-eastern Norway, tracing internal migration in the provinces surrounding Tromsø and Trondheim during the second half of the 19th century, and the immigration of Jews from 1851 to WWII.

- The struggle of the Sami who trekked with their reindeer between winter pastures in Sweden and summer pastures on the coast of Norway.

- The connection between marriage and ethnicity in Karlsøy 1770-1900 and more generally the classification of ethnicity in Northern Norway.

A few highlights can illustrate the impact of the historical microdata research. We now know that infant mortality levels and childcare practices were inherited over the generations, and that the life conditions of little girls could influence the survival chances of their future children. Premarital sexual relations were usual, and around 1800 up to half of the brides would be pregnant at the altar. We also know that life expectancy decided when means of livelihood became available and thus influenced the timing of marriages. Studies of ethnic marriage patterns have shown resistance against Sami-Norwegian mixed marriages, while the Kvens could function as catalysts to promote inter-ethnic marriage. Primogeniture predominated among the ethnic Norwegians, while the Sami practised ultimogeniture. The family structure varied between different parts of the country, but a general trend was that the relocation of production out of the household to the secondary and tertiary economic sectors from the late 19th century made more women householders, lowered the age at marriage, raised children longer at home and reduced the household size. Emigrant numbers proved to be higher than previously estimated, and when compared to present day international migration, current border restrictions especially limit the emigration of poor people, although this finding may only be valid for urban emigrants.

While priority during the latest decades was given to mortality, migration and family history studies, there is now a development towards studies of social medicine history and to cover the understudied middle decades of the 20th century. Central to this are the use of longitudinal methodology, necessitating record linkage rather than using sources separately, and the building of our Historical Population Register.

Today we have over 10 million manually transcribed person entities from 19th and early 20th century population censuses, and professional transcribers and volunteers have manually transcribed approximately 20 million person entities from the church books. In addition, about 60-80 million person entities transcribed by the previously mentioned genealogy companies, have now been transferred to be used in the Population Register. Our fine-tuned algorithms for record linkage have a success rate of $60-80 \%$ for linkage between decennial censuses. For areas where we have a long time-series of 
transcribed church books, complete life trajectories have been constructed for the majority of the population.

The most recent development is that the Norwegian Research Council in 2021/2022 granted over 2.5 million Euros for the development of integrated "Historical Registers", which will include the Historical Population Register together with the Property Register and other nominative databases.

In the years to come we will strive to develop optimized automatic systems for preprocessing the 6080 million data entries, primarily through machine learning $(\mathrm{ML})$ models for standardization and for coding. Given that only a selected group of variables were transcribed by the genealogy companies, we will continue our work on developing ML models for transcription of handwritten text (compare Pedersen et al., 2022). A priority will be given to cause of death data.

Through the successful cooperation with the project "Mapping Human Capital of Nordic Countries", we aim to expand the Historical Population Register with individual level data on education, which today have a national coverage from 1950 and onwards. With the implementation of educational data from a variety of sources, we will be able to go back to the beginning of the 19th century. The recently adopted partner in the Norwegian School of Economics supplies us with individual level income data.

Another aim is to develop online resources, videos and teaching materials as the basis of a resource which we conceive as a 'historical laboratory'. HistLAB, as it has been named, will be offered through our web portal, and researchers, teachers and students from senior secondary schools, colleges and universities will be able to use it along with those data in HPR which are open access.

We believe the establishment of HistLAB will alert established academics, new generations of researchers and students to the existence and scope of our population register and encourage them to use and promote this impressive resource.

\section{REFERENCES}

Abramitzky, R., Boustan, L. P., \& Eriksson, K. (2012). Europe's tired, poor, huddled masses: Selfselection and economic outcomes in the age of mass migration. American Economic Review, 102(5), 1832-1856. doi: 10.1257/aer.102.5.1832

Abramitzky, R., Boustan, L. P., \& Eriksson, K. (2013). Have the poor always been less likely to migrate? Evidence from inheritance practices during the age of mass migration. Journal of Development Economics, 102(C), 2-14. doi: 10.1016/j.jdeveco.2012.08.004

Åkerman, S. (1978). Towards an understanding of emigrational processes. In W. H. McNeill \& R. S. Adams (Eds.), Human migration: Patterns and policies (pp. 287-306). London: Bloomington, IN.

Alter, G., \& Mandemakers, K. (2014). The Intermediate Data Structure (IDS) for longitudinal historical microdata, version 4. Historical Life Course Studies, 1, 1-26. doi: 10.51964/hlcs9290

Backer, J. (1961). Dødeligheten og dens årsaker i Norge 1856-1955 [Mortality and its causes in Norway 1856-1955]. Oslo: Statistics Norway.

Brändström, A. (1988). The impact of female labour conditions on infant mortality: A case study of the parishes of Nedertorneå and Jokkmokk, 1800-96. Social History of Medicine, 1(3), 329-358. doi: 10.1093/shm/1.3.329

Brochmann, G., \& Kjeldstadli, K. (2008). A history of immigration: The case of Norway 900-2000. Oslo: Universitetsforlaget.

Bull, H. (2000). Hushold og generasjonsskifter i Rendalen 1762-1900: Attesamfunnets siste skanse? [Household and generational change in Rendalen 1762-1900: The last stronghold of the family society?]. Oslo: Universitetet i Oslo. Retrieved from http://files.christian-asphaug.webnode. no/200000309-55ce756c8c/1762-1900\%20H.Bull\%20\%C3\% 86ttesamfunnets\%20siste\% 20 skanse \%20del\%201.pdf

Bull, H. H. (2005). Deciding whom to marry in a rural two-class society: Social homogamy and constraints in the marriage market in Rendalen, Norway, 1750-1900. International Review of Social History, 50(S13), 43-63. doi: 10.1017/S0020859005002063

Bull, H. H. (2006). Marriage decisions in a peasant society: The role of the family of origin with regard to adult children's choice of marriage partner and the timing of their marriage in Rendalen, Norway, 1750-1900 (Doctoral dissertation). Faculty of Humanities, University of Oslo Unipub, Oslo. 
Bygren, L. O., Tinghög, P, Carstensen, J., Edvinsson, S., Kaati, G., Pembrey, M. E., \& Sjöström, M. (2014). Change in paternal grandmothers' early food supply influenced cardiovascular mortality of the female grandchildren. BMC Genetics, 15. doi: 10.1186/1471-2156-15-12

Coale, A. J., Anderson, B. A., \& Härm, E. (1979). Human fertility in Russia since the nineteenth century. Princeton: Princeton University Press.

Drake, M. (1969). Population and society in Norway, 1735-1865. Cambridge: Cambridge University Press.

Dyrvik, S. (1983). Historisk demografi. Ei innføring i metodane [Historical demography. An introduction to the methods]. Bergen: Universitetsforlaget

Dyrvik, S. (1993). Farmers at sea: A study of fishermen in north Norway, 1801-1920. Journal of Family History, 18(4), 341-356. doi: 10.1177/036319909301800404

Dyrvik, S. (1997). Spedbarnsdøden i Etne prestegjeld 1716-1900 [Infant mortality in Etne parish 1716-1900]. In G. A. Ersland, E. Hovland \& S. Dyrvik (Eds.), Festskrift til Historisk institutts 40års jubileum 1997 (pp. 131-150). Bergen: University of Bergen.

Dyrvik, S., \& Alsvik, M. K. (1987). Gjennombrotet for fødselsregulering i Stavanger 1900-1935 [The breakthrough for birth regulations in Stavanger town 1900-1935]. Bergen: University of Bergen.

Edvinsson, S., \& Engberg, E. (2020). A database for the future. Major contributions from 47 years of database development and research at the Demographic Data Base. Historical Life Course Studies, 9, 173-196. doi: 10.51964/hlcs9305

Edvinsson, S., Garðarsdóttir, O., \& Thorvaldsen, G. (2008). Infant mortality in the Nordic countries, 1780-1930. Continuity and Change, 23(3), 457-486. doi: 10.1017/S0268416008006917

Eide, O. J., \& Thorvaldsen, G. (2011). Historisk befolkningsregister: Oversikt over emigrasjonen [The Historical Population Register: An overview of emigration]. Heimen, 48(3), 207-228.

Eliassen, J. (1981). Fine jomfruer, gravide bruder og ugifte mødre. Forholdene i Moss rundt år 1800 [Nice virgins, pregnant brides and unwed mothers. Conditions in Moss town about 1800]. In J. Eliassen \& S. Sogner (Eds.), Bot eller bryllup. Ugifte mødre o gravide bruder i det gamle samfunnet [A penance or a wedding. Unmarried mothers and pregnant brides in traditional society] (pp. 81-91). Oslo: Universitetsforlaget.

Engelsen, R. (1983). Mortalitetsdebatten og sosiale skilnader i mortalitet [The mortality debate and social differences in mortality]. Historisk tidsskrift, 62(2), 161-202.

Forsdahl, A. (1973). Momenter til belysning av den høye dødelighet i Finnmark fylke: Kan den høye dødelighet i dag være en senfølge av meget dårlige levevilkår i barne- og ungdomsalderen? [Factors shedding light on the high mortality rate in Finnmark county: Can the high mortality rate today be a late consequence of very poor living conditions in childhood and adolescence?]. Tidsskrift for den Norske Lægeforening, 93(10), 661-667.

Fure, E. (1980). Den ekteskapelige fruktbarhet i Kolbu, ca. 1870-1910. En studie av fruktbarhetsfallets innledningsfase [Marital fertility in Kolbu, approximately 1870-1910. A study of fertility decline during the introductory phase] (Doctoral dissertation). University of Oslo, Oslo.

Fure, E. (1986). Gamle i flergenerasjonsfamilier - en seiglivet myte? [Elderly in multi-generational families - a tenacious myth?]. Historisk tidsskrift, 1, 16-35.

Fure, E. (2000). Spedbarnsdødeligheten og sosiale forskjeller i Asker og Bærum 1814-1878. En metode for studier på individnivå [Infant mortality and social differences in Asker and Bærum parishes 1814-1878. A method for studies at the individual level]. Heimen, 37(4), 293-304.

Fure, E. (2002). Is it the mother's health that really matters? Infant mortality in the parish of Asker and Bærum 1814-1878. In H. Sandvik, K. Telste \& G. Thorvaldsen (Eds.), Pathways of the past: Essays in honour of Sølvi Sogner on her 70th anniversary 15. March 2002 (pp. 73-90). Oslo: Novus.

Gjelseth, M. (2000). Relasjonsdatabaser som verktøy $i$ en historisk-demografisk studie [Relational databases as a tool in a historical-demographic study] (Master thesis). University of Oslo, Oslo.

Gjernes, M. (2004). Dei fyrste jødiske innvandrarane i Kristiania [The first Jewish immigrants in Kristiania/ Oslo]. Historisk tidsskrift, 83(3), 385-416. doi: 10.18261/ISSN1504-2944-2004-03-02

Haavet, I. E. (1982). Avvik eller uhell? Ugifte foreldre omkring 1800 - En sosial analyse [Deviation or accident? Unmarried parents around 1800 - A social analysis] (Master thesis). University of Bergen, Bergen.

Hajnal, J. (1965). European marriage patterns in perspective. In D. V. Glass \& D. E. C. Eversley (Eds.), Population in history. Essays in historical demography (pp. 101-144). London: Edward Arnold.

Halvorsen, B., \& Indseth, K. (1875). Befolkningsutviklingen i Ullensaker 1733-1845, en demografisk unders $\varnothing$ kelse [Population development in Ullensaker parish 1733-1845, a demography] (Doctoral dissertation). University of Oslo, Oslo. 
Hubbard, W. H. (1995). Historical demography. In W. H. Hubbard, J. E. Myhre, T. Nordby \& S. Sogner (Eds.), Making a historical culture: Historiography in Norway (pp. 311-324). Oslo: Scandinavian University Press.

Kjeldstadli, K. (Ed.). (2003). Norsk innvandringshistorie [Norwegian immigration history] (Vols. I-III). Oslo: Pax.

Knudtsen, M. S. (1997). Fra frelse til helse: Spedbarnsdødelighet og omsorgssyn i Norge ca 17001830 med særlig vekt på forholdene $i$ Vår Frue sokn, Trondheim [From salvation to health: Infant mortality and views on care in Norway approximately 1700-1830 with special emphasis on the conditions in Our Lady parish, Trondheim] (Doctoral dissertation). Norges teknisknaturvitenskapelige universitet, Trondheim.

Koren, E. (1979). Utvandringen fra Ullensaker 1867-99: En sosialhistorisk undersøkelse [The emigration from Ullensaker municipality 1867-99: A social history study] ( Master thesis). University of Oslo, Oslo.

Kovacevic, M. (2020). Tuberculosis and society in Tromsø 1878-1920. An epidemiological study of tuberculosis mortality within societal differences (Master thesis). UiT The Arctic University of Norway, Tromsø.

Langholm, S. (1974). Historie på individnivå. Omkring Ullensaker-undersøkelsen — et mikrohistorisk eksperiment [History at the individual level. About the Ullensaker survey - a microhistorical experiment]. Historisk tidsskrift, 53, 243-272.

Langholm, S. (1975). Short-distance migration, circles and flows: Movement to and from Ullensaker according to the population lists of 1865. Scandinavian Economic History Review, 23(1), 36-62. doi: 10.1080/03585522.1975.10407804

Larsen, B. (2008). Giftermål og etnisitet. Samer, nordmenn og ekteskap i Karlsøy 1770-1900 [Marriage and ethnicity. Sami, Norwegians and marriages in Karlsøy parish 1770-1900] (Doctoral dissertation). University of Tromsø, Tromsø. Retrieved from https://hdl.handle.net/10037/7059

Lindbekk, K., \& Opach, T. (2020). Befolkningsutvikling i masseutvandringens tid Trøndelag 18661914 [Population development in a period of mass emigration Trøndelag 1866-1914]. Heimen, 57(1), 23-46. doi: 10.18261/issn.1894-3195-2020-01-03

Lindbekk, K. E. (2017). Fast og tilstrekkelig levebrød. Livsløpene til trøndere født i 1855 og foreldrene deres 1815-1910 [Permanent and adequate livelihood. The life courses of people born in Trøndelag 1855 and their parents 1815-1910] (Doctoral dissertation). University of Oslo, Oslo.

Linge, T. (1977). Befolkningsutviklinga i Nordal 1737-1865 [Population development in Nordal parish 1737-1865] (Master thesis). University of Oslo, Oslo.

Lithell, U.-B. (1988). Childcare - a mirror of women's living conditions: A community study representing 18th and 19th century Ostrobothnia in Finland. In A. Brändström \& L.-G. Tedebrand (Eds.), Society, health and population during the demographic transition (pp. 91-108). Umeå: Umeå University.

Mamelund, S.-E. (2001). Mortality and life expectancy in Rendalen and Norway 1770-1900: Period and cohort perspectives. In L.-G. Tedebrand \& P. Sköld (Eds.), Nordic demography in history and present-day society (pp. 201-231). Umeå: Umeå University.

Mamelund, S.-E. (2006). A socially neutral disease? Individual social class, household wealth and mortality from Spanish influenza in two socially contrasting parishes in Kristiania 1918-19. Social Science \& Medicine, 62(4), 923-940. doi: 10.1016/j.socscimed.2005.06.051

McCaa, R. (1989). Populate. A microcomputer projection package for aggregative data applied to Norway, 1736-1970. Annales de Démographie Historique, 287-298. doi: 10.3406/ adh.1989.1747

Mølmann, N. P. (2004). Spedbarnsdødeligheten $i$ en ishavsby: Hammerfest 1801-1900 [Infant mortality in an Arctic town: Hammerfest 1801-1900] (Master thesis). University of Oslo, Oslo.

Mørkhagen, S. (2009). Farvel Norge: Utvandringen til Amerika 1825-1975 [Farewell Norway: The emigration to America 1825-1875]. Oslo: Gyldendal.

Pedersen, A. G. (2007). Dødelighet og dødsårsaker [Mortality and causes of death]. In R. R. Bore (Ed.), På liv og død. Helsestatistikk i 150 år [Life and death. Health statistics during 150 years]. Oslo: Statistics Norway.

Pedersen, B.-R., Holsbø, E., Andersen, T., Shvetsov, N., Ravn, J., Sommerseth, H. L., \& Bongo, L. A. (2022). Lessons learned developing and using a machine learning model to automatically transcribe 2.3 million handwritten occupation codes. Historical Life Course Studies, 12, 1-17. doi: 10.51964/hlcs11331

Pitkänen, K. (1983). Infant mortality decline in a changing society. Finnish yearbook of population research, 21, 46-74. doi: 10.23979/fypr.44768 
Quaranta, L., Broström, G., van Dijk, I., Donrovich, R., Edvinsson, S., Engberg, E., . . . Sommerseth, H. L. (2017). Intergenerational transfers of infant mortality in historical contexts: A comparative study of five European populations. Paper presented at the Population Association of America (PAA), Chicago, IL, USA.

Quaranta, L., \& Sommerseth, H. L. (2018). Introduction: Intergenerational transmissions of infant mortality using the Intermediate Data Structure (IDS). Historical Life Course Studies, 7, 1-10. doi: 10.51964/ hlcs9288

Randsborg, H. B. (1979). Befolkningsutviklingen i Bø i Telemark: 1727-1815 [Population development in Bø parish in Telemark county: 1727-1815] (Master thesis). University of Oslo, Oslo.

Ruggles, S. (1994). The transformation of American family structure. American Historical Review, 99(1), 103-128. doi: 10.1086/ahr/99.1.103

Sogner, S. (1978). Familie, husstand og befolkningsutvikling [Family, household and population development]. Heimen, XVII.

Sogner, S. (1979). Folkevekst og flytting. En historisk demografisk studie $i$ 1700-årenes Øst-Norge [Population growth and relocation. A historical demographic study of 18th-century eastern Norway] (Doctoral dissertation). Universitetsforlaget, Oslo

Sogner, S. (1990). Far sjøl i stua og familien hans: Trekk fra norsk familiehistorie før og nå [The father himself in the living room and his family: Aspects of Norwegian family history before and now]. Oslo: Universitetsforlaget.

Sogner, S. (2000). A case study of women's role and infant mortality. In S. Sogner \& G. Hagemann (Eds.), Women's politics and women in politics. In honour of Ida Blom (45-67). Oslo: Cappelen Akademisk Forlag.

Sogner, S. (2009). The Norwegian stem family: Myth or reality? In A. Fauve-Chamoux \& E. Ochiai (Eds.), The stem family in Eurasian perspective. Revisiting house societies, 17th-20th centuries (pp. 151-172). Bern: Peter Lang.

Sogner, S. (2012). "Og skuta lå i Amsterdam ...": Et glemt norsk innvandrersamfunn i Amsterdam 1621-1720 ["And the sail ship was in Amsterdam ...": A forgotten Norwegian immigrant community in Amsterdam 1621-1720]. Oslo: Aschehoug.

Sogner, S. (2016). Historical demography in Norway 1960-2010. In A. Fauve-Chamoux, I. Bolovan \& S. Sogner (Eds.), A global history of historical demography: Half a century of interdisciplinarity (pp. 499-512). Bern: Peter Lang.

Sogner, S., Fure, E., \& Randsborg, H. B. (1984). Fra stua full til tobarnskull: Om nedgangen i barnetall i norske familier i de siste 200 år, med særlig vekt på perioden 1890-1930 [From a housefull to parity two: On the decline in child numbers during the last 200 years, emphasizing 1890-1930]. Oslo: Universitetsforlaget.

Sogner, S., \& Thorvaldsen, G. (2001). Surnames as proxies for place of origin in the 1801 census for Norway. Paper presented at the Nordic Demographic Symposium, Tjøme, Norway.

Solli, A. (1995). Individ - hushald - samfunn: Fisk og jord som grunnlag for hushaldsetableringa $i$ Norge kring år 1800 [Individual - household - society: Fish and soil as a basis for the establishment of households in Norway around the year 1800] (Master thesis). University of Bergen, Bergen. Retrieved from https://hdl.handle.net/1956/6286

Solli, A. (2004). Livsløp - familie - samfunn: Endring av familiestrukturar i Norge på 1800-talet [Life course - family - society: Changing family structures in Norway in the 19th century] (Doctoral dissertation). University of Bergen, Bergen. Retrieved from https://hdl.handle.net/1956/3061

Sommerseth, H. L. (2003). Spedbarnsdødeligheten i Tana i perioden 1840-1914 [Infant mortality in Tana in the period 1840-1914] (Master thesis). University of Tromsø, Tromsø.

Sommerseth, H. L. (2006). Fikk spedbarnet morsmelk? Spedbarnsernæringen i Finnmark og en problematisering av hvordan denne påvirket det relativt høye dødelighetsnivå i Tana i perioden 1840-1914 [Did the infant receive breast milk? The infant nutrition in Finnmark county and problematicing how this affected the relatively high mortality rate in Tana parish during the period 1840-1914]. Heimen, 43(1), 3-14.

Sommerseth, H. L. (2011a). The effect of ethnicity and economy upon intergenerational coresidence: Northern Norway during the last part of the nineteenth century. Journal of Family History, 36(3), 263-285. doi: 10.1177/0363199011406634

Sommerseth, H. L. (2011b). Endring i samisk og norsk husholdsstruktur: Nord-Troms og Finnmark i perioden 1865 til 1900 [Changing Sami and Norwegian household structure: North Troms and Finnmark counties during the period 1865 to 1900]. Historisk tidsskrift, 90(1), 33-61 doi: 10.18261/ISSN1504-2944-2011-01-03 
Sommerseth, H. L. (2018). The intergenerational transfer of infant mortality in Northern Norway during the 19th and early 20th centuries. Historical Life Course Studies, 7, 69-87. doi: 10.51964/ hlcs9284

Sommerseth, H. L., \& Thorvaldsen, G. (2016). Masculine responsibility across generations: Living arrangements in a Norwegian parish around 1900. The History of the Family, 21(1), 21-37. doi: $10.1080 / 1081602 \times .2015 .1069204$

Sommerseth, H. L., \& Walhout, E. C. (2019). Deaths in a city: A view from the 19th century church registers in Norway. In E. Glavatskaya, G. Thorvaldsen, G. Fertig \& M. Szoltysek (Eds.), Nominative data in demographic research in the East and the West (pp. 185-201). Ekaterinburg: Ural University Press. Retrieved from https://elar.urfu.ru/bitstream/10995/73898/1/978-5-7996-2656-3_2019. pdf

Statistics Norway. (1980). Folketeljinga 1801. Ny bearbeiding [Population census 1801. Reprocessed]. Oslo: Central Bureau of Statistics. Retrieved from https://www.ssb.no/a/histstat/nos/nos_b134. pdf

Statistics Norway. (1995). Historisk statistikk 1994 [Historical statistics 1994]. Oslo: Statistics Norway. Retrieved from https://www.ssb.no/a/histstat/nos/nos_c188.pdf

Sunde, R. (2001). Vikjer ved fjorden, vikjer på prærien: Ein demografisk-komparativ studie med utgangspunkt $i$ Vik $i$ Sogn [Vik people by the fjord, Vik people on the prairie: A demographiccomparative study with a starting point in Vik parish in Sogn county] (Doctoral dissertation). Høgskulen i Sogn og Fjordane, Sogndal.

Szołtysek, M., Ogórek, B., \& Gruber, S. (2021). Global and local correlations of Hajnal's household formation markers in historical Europe: A cautionary tale. Population Studies, 75(1), 67-89. doi: 10.1080/00324728.2020.1832252

Thorvaldsen, G. (1977). Bruk av elektronisk databehandling i bearbeidelsen av lokalhistoriske kilder [Using electronic data processing in the processing of local history sources]. Heimen, XVII, 493498.

Thorvaldsen, G. (1978). Registreringssentral for historiske data [The Norwegian Historical Data Centre]. Retrieved from https://rhd.uit.no/indexeng.html

Thorvaldsen, G. (1979). Registreringssentral for historiske data. Rapport fra prøveprosjektet 1/8 1978 til 28/2 1979 [The Norwegian Historical Data Centre. Report from the pilot project 1.8.1978 to 28.2.1979]. Institute of Social Sciences, University of Tromsø: Tromsø.

Thorvaldsen, G. (1995). Migrasion i Troms $i$ annen halvdel av 1800-tallet. En kvantitativ analyse av folketellingene 1865, 1875 og 1900 [Migration in Troms province in the second half of the 19th century. A quantitative analysis of censuses 1865, 1875 and 1900] (Doctoral dissertation). Universitetet i Tromsø, Tromsø. Retrieved from https://hdl.handle.net/10037/1390

Thorvaldsen, G. (1996). Håndbok i registrering og bruk av historiske persondata [Manual for registration and use of historical personal data]. Oslo: Tano Aschehoug.

Thorvaldsen, G. (1998). Historical databases in Scandinavia. The History of the Family. An International Quarterly, 3(3), 371-383. doi: 10.1016/S1081-602X(99)80252-8

Thorvaldsen, G. (2002). Rural infant mortality in nineteenth century Norway. In S. Sogner (Ed.), Studies in mortality decline. Report from the Mortality Studies Group (75-113). Oslo: Centre for Advanced Study. doi: 10.3384/hygiea.1403-8668.023175

Thorvaldsen, G. (2011). Using NAPP census data to construct the Historical Population Register for Norway. Historical Methods, 44(1), 37-47. doi: 10.1080/01615440.2010.517470

Thorvaldsen, G. (2014). Religion in the census. Social Science History, 38(1-2), 203-220. doi: 10.1017/ ssh.2015.16

Thorvaldsen, G. (2018a). Censuses and census takers: A global history. London: Routledge.

Thorvaldsen, G. (2018b). Emigrants in the Historical Population Register of Norway. Journal of Migration Research, 4(2), 264-288. doi: 10.1163/23519924-00402003

Thorvaldsen, G. (2019). Internal migration in 19th and 20th century Norway. An overview 1865 to 1960. In E. Glavatskaya, G. Thorvaldsen, G. Fertig \& M. Szoltysek (Eds.), Nominative data in demographic research in the East and the West (pp. 166-184). Ekaterinburg: Ural University Press. Retrieved from https://elar.urfu.ru/bitstream/10995/73898/1/978-5-7996-2656-3_2019.pdf

Thorvaldsen, G., Sommerseth, H. L., \& Holden, L. (2020). Anvendelser av Norges historiske befolkningsregister [Interfaces to Norway's Historical Population Register]. Heimen, 57(3), 230243. doi: 10.18261/issn.1894-3195-2020-03-05 